DOI: 10.2478 /ausp-2014-0005

\title{
Inventing the Enemy. When Propaganda Becomes History
}

\author{
Anca ANDRIESCU GARCIA \\ Valdosta State University, Georgia, USA \\ English Language Institute \\ garciaanca@yahoo.com
}

\begin{abstract}
Umberto Eco's latest novel, The Prague Cemetery, has a complicated metatextual plot in which, as the writer himself stated, he attempts to create the most repugnant of all literary characters, in other words, some sort of "perfect loather" who detests everyone, including himself. I will discuss the various stereotypes of otherness, the way these stereotypical images interact, and how the author weaves the prejudices related to almost every European nationality, but mostly to the Jews, into the image of the "supreme enemy," an image divested of any ornament and so presumptuous that it becomes almost dense. Moreover, in relation to the image I mentioned above, I analyse the mechanisms language uses as a vehicle of deception especially when it describes what is familiar in propagandist texts. I also focus on the different fictional filters applied to real historical events (and texts) in order to entice the reader into trying to decipher a complex and factitious labyrinth in which the barrier between truth and fiction no longer matters, it is purely accidental, and has only one purpose-to generate conspiracies.
\end{abstract}

Keywords: Enemy, Propaganda, Jews, Metatext

"Having an enemy is important not only to define our identity but also to provide us with an obstacle against which to measure our system of values and, in seeking to overcome it, to demonstrate our own worth. So when there is no enemy, we have to invent one" $(2012,46)$, Umberto Eco wrote in the essay that gives the title of one of his latest books, Inventing the Enemy. Indeed, this seems to be the key metaphor at the beginning of his novel The Prague Cemetery, where the main character, Simone Simonini, admits he loves nobody and, in fact, hates everyone: for him the Germans, who "produce twice the feces of a Frenchman" represent "the lowest level of humanity" $(2010,102)$ imaginable, the French are "vicious" and "kill out of boredom" (134), while an Italian is from his point of view nothing but an "untrustworthy, lying, contemptible traitor [...], consistent only in changing sides with the wind" (161). Later on this description will fit him perfectly as he is a forger who works for whomever pays him the most, and who 
throughout the novel commits numerous murders, but never feels guilty. He also hates the priests, among which "the worst of all, without doubt, are the Jesuits," yet that does not stop him to walk around disguised as one whenever it suits him, their "blood brothers, the Masons" (181), and the women, in spite of what little he knows of them. And if this revelation of his animosities was not enough to convey a full image of his personality, the character makes it even clearer by declaring emphatically at the end of his exposé, paraphrasing the well-known Cartesian belief, “Odio ergo sum. I hate therefore I am” (222).

His first choice in the hierarchy of the most hated ethnicities would be, however, the Jew who, as his grandfather told him, belongs to a nation of "the most godless people," who "work only for the conquest of this world," and who, apart from his monstrous being with "eyes that spy on you, so false as to turn you pale, those unctuous smiles, those hyena lips over bared teeth, those heavy, polluted brutish looks, those restless creases between nose and lips, wrinkled by hatred" etc., embodies the flaws of many other ethnicities combined being "as vain as a Spaniard, ignorant as a Croat, greedy as a Levantine, ungrateful as a Maltese, insolent as a Gypsy, dirty as an Englishman, unctuous as a Kalmyk, imperious as a Prussian and as slanderous as anyone from Asti..." (90-94). The list of negative stereotypes in the text is almost infinite; it creates a textual labyrinth in which the writer inserts elements of popular hatred and historical prejudices together with Gothic, Mannerist, Balzacian, scientific etc. collages, all meant to build the image of a grotesque, utterly despicable character placed in the middle of a metatextual harangue which puzzles the most sophisticated reader and which is obviously meant to provoke an intense reaction of shock and repulsion.

As a character, Simonini will gain an even more ambiguous consistency at the end of the novel when the writer reveals that he is "the only fictitious character" in the story, everyone else, including his grandfather, Captain Simonini, a "mysterious writer of a letter to Abbé Barruel" (Eco 2010, 5541), the well-known conspiracy theorist in the nineteenth century, is a real, historical figure. And most of the book reviewers seem to be completely content with this statement. Yet the name Simonini, which according to Eco is derivative from the name of a suppressed Catholic saint, Saint Simon of Trent, allegedly killed by the Jews, can be found in Eco's essays, previous to the release of the novel. ${ }^{1}$ Moreover, in the novel he has an obviously dual, schizoid personality: he writes a journal both as Simonini and as the Abbé Dalla Piccola and, at some point in the text, assumes the title of Captain in memory of his grandfather. The journal as a literary technique, as well as the double are not new conventions, especially in the Gothic literature

1 In the collection of articles entitled Turning Back the Clock, published in 2006, Eco mentions the Abbé Barruel, who believed the French Revolution was a result of the plot put together by the Templars and the Masons, but whose views were amended by a certain Captain Simonini, "who pointed out to him that those who pulled the strings were the perfidious Jews" (Eco 2008, 314). 
with which the novel has clear affinities, but the fact that the alter ego of the protagonist addresses himself as "Captain Simonini" makes the fine line between him as a character and the grandfather as a historical person according to Eco even harder to define. Moreover, in an interview with a Norwegian television station when speaking about his novel, Eco points out that Simonini is meant to be repugnant in order not to be taken seriously, and that he is absolutely true, although invented. In other words, Eco's character is impossible to be read in a textual vacuum, as a regular narrative being because of an unconventional dialectical game between his reality and his textual nature.

The journal itself, the pretext for the novel, represents another clue to this dialectic. Simonini hates the Jews but writes at the suggestion of the Jewish doctor Sigmund Froïde, an obvious reference to Freud, whom he met at the restaurant Chez Magny. The character suffers from amnesia and tries to recover his memory through writing and not through confession, being too afraid, for obvious reasons, to talk about his past with the psychoanalyst. Apart from Simonini and his alter ego who both use the first person narration, the novel also includes a Narrator-some believe that this voice belongs to Eco himselfwhose role seems to be to put order into the journal. Freud's presence in the novel and these narrative instances could possibly be related, in my opinion, to the Freudian well-known model of the mind structured on three levels: unconscious, ego, and superego, with every one of these narrators corresponding to a stratum. That explanation does not answer the question why the writer would go to such great lengths, would create such a florid and complicated textual scheme for such a disruptive, malicious, and, ultimately, nonsensical character. After all, regardless of the mosaic of intertextual allusions, mainly stereotypical, and the effort to recreate the image of the late 1800s, Simonini is not exactly an innovative figure and thus not very easy to digest (even the culinary references do not make up for this!). I think, however, that the answer lies not necessarily in his disruptive nature, but rather in the way this nature and the entire plot of the novel position themselves toward reality and in how their fictitiousness transforms into real throughout the novel.

Alain Badiou in the book entitled The Century asserts that when reconstructing history the real question for philosophers is not what took place in a certain period of time-his book speaks about the twentieth century-but rather what people in that period believed in. He calls this a search for the "uninherited thoughts" (Badiou 2012,3) of the time. Only if we admit, for instance, that what the Nazis did was a form of thought, and avoid categorising it religiously as evil can we distinguish the truth about it. The best method to investigate the last century is to extract from among the century's productions the ones that singularise it among the other centuries, the "documents or traces indicative of how the century thought itself" (Badiou 2012, 3). In this way, in relationship 
with history, "we might manage to replace the passing of judgments with the resolution of some problems" (Badiou 2012, 6).

Thus, from Badiou's point of view, the evaluation of the twentieth century must be done bearing in mind what he later on defines as its "passion for the real," a construct "devoid of morality" because "morality is a residue of the old world" (63). And, Badiou continues, there are two paths generated by this "passion of the real" of the twentieth century-the one of "terroristic nihilism," one which is ultimately "hostile to every action as well as every thought," and "one that attempts to hold onto the passion without falling for the paroxysmal charms of terror," which attempts not to destroy the reality, but to purify it to the point where it can detect the "minuscule difference, the vanishing point that constitutes it." Both paths are obsessed with the question of the new-hence the image of the new man with two opposite meanings: for the fascists the new man is "in part the restitution of the man of old, of the man who had been eradicated, had disappeared, had been corrupted," and in this process of purification the goal is to return to a vanished origin; while for the marxisant communism the new man is a new creation, who "emerges from the deconstruction of historical antagonisms" (Badiou 2012, 65). The twentieth century oscillates between these two extreme images-one of mythical origins, one antagonistic to everything before it, and presumably completely new.

In Eco's novel, the protagonist's type of reasoning, because of or in spite of the multiple racial and ethnic stereotypes, is situated beyond the limit of morality, beyond good and evil, beyond the possibility of any judgment. His "Odio ergo sum" is a mere thought, not a passionate statement. He is not charming, he is definitely not a hero, but he is not necessarily an anti-hero either because after the first few pages the reader somehow grows accustomed to his vitriolic personality which is so outrageous that it becomes benign. The focus shifts now towards the plot of the novel which ultimately concerns a famous fiction published for the first time in 1903, although obviously written earlier, known as The Protocols of the Elders of Zion. In spite of the fact that the Protocols were not originals, they indubitably influenced the past century because they became a central part of Hitler's propaganda, they were his "warrant for genocide" as the historian Norman Cohn suggested, and thus I would call them, in Badiou's terms, some of the most important "forms of thoughts."

As Eco noticed in Turning Back the Clock. Hot Wars and Media Populism, the polemic which led to the writing of the Protocols started after Abbé Barruel wrote his Mémoires pour servir à l'istoire du jacobinisme, in 1797. The entire nineteenth century is thus shaped by the debate concerning Jews as the enemies, especially in France. Hence when the Protocols were published the public opinion was already prepared to believe in them in spite of their style resembling feuilletons. They speak of a secret meeting of Jewish leaders conspiring to take over the 
world. It is, clearly, a text put together precisely to create a story of conspiracy, but, as Eco notices, "the extraordinary thing about the Protocols of the Elders of Zion isn't the story of their production but that of their reception. [...] Amazingly, this fake is born again and again from the ashes every time someone comes up with the cast-iron proof of its falseness" (Eco 2008, 317-318).

Moreover, the reasoning [of those who resist the evidence of their falseness] is impeccable: 'since the Protocols say what I say in my story, they confirm my words.' Or: 'the Protocols confirm the story I have drawn from them, and hence they are authentic.' In other words, it is not the Protocols that engendered anti-Semitism; it is the profound need to identify an enemy that prompts people to believe in them. (Eco 2008, 319)

And it is not a first, as René Girard once stated: in many of the medieval documents speaking about the Jew as the scapegoat, the source of evil, and the violence of the persecutions that follow such beliefs, "the probable and improbable interact in such a way that each explains and justifies the presence of the other" $(1986,10)$. This "profound need to identify an enemy" and the will to decipher the way public hatred focuses on a particular one is what makes Eco's literature become an exploration of how the history of ideas in the twentieth century was shaped.

Seen as the core of the novel, the story of the Protocols casts a different light on the character. He is, after all, another part of the almost impermeable labyrinth of hoaxes and intertextual relationships that surrounds this fiction which is in its turn fictionalized in the novel. Simonini might be the result of a textual collage, but his function is very specific-his actions and picaresque adventures are meant not only to explain the writing of the Protocols, but also to bring together, in a plausible narrative scheme, all the real, historical players that are known to have taken part, willingly or unwillingly, in the creation of the document.

Simonini's grandfather is just the starting point of his journey-the character will be an observer, even a tangential one, of all the major events of the time: the Communist Manifesto, the Franco-Prussian War, the Dreyfus affair, and Drumont's book are among the most notable ones. Napoleon III, Dumas, Marx, Garibaldi, and Dostoyevsky are just a few names mentioned in the text. Simonini is a forger of legal documents and a seller of consecrated hosts, but in reality he works for the French and the Russian secret services. In chapter 11 Lagrange, the head of the French secret service, shows him a copy of Maurice Joly's book, Dialogue aux enfers entre Machiavel et Montesquieu, which is historically proven to have served as one of the main sources of the Protocols. He infiltrates the prison to speak with the author who represents the epitome of resignation: "you cannot change the world through ideas" (Eco 2010, 2240), Joly says at some 
point, but the rest of the novel will prove him wrong. Simonini also dismantles the mechanisms of conspiracy when he puts together a plot against Napoleon III only to report it. Eco's wit follows every single recipe of small level paranoid machinations in order to, it seems, prepare the reader for the real story in the following chapter. The novel is in this point serious and humorous in the same time, the rhetoric surrounding the plot is built on the classical pattern of any conspiracy which, according to P. Knight quoted by Adrian S. Wisnicki, takes itself seriously, while also "casts satiric suspicion on everything, even its own pronouncements" (Wisnicki 2008, 271).

This satiric tone is maintained in Chapter 12, the most important in the novel, when Simonini has the revelation that

there was an anti-Jewish market not just among all the descendants of Abbé Barruel (and there were quite a few of them), but also among revolutionaries, republicans and socialists. The Jews were the enemy of the altar, but also of the ordinary people whose blood they sucked. And they were also the enemy of the throne, depending on who governed (Eco 2010, 2461).

Thus Simonini decides "to work on the Jews" and he gets the chance to do so right away when Lagrange asks him to meet his Russian counterpart represented by colonel Dimitri, who plans to gather information in order to direct the Russian peasants' discontent against the Jews instead of the government. The passages that follow are a masterful analysis of what makes manipulation and propaganda easy to believe and thus extremely dangerous. As "revelations have to be out of the ordinary, shocking and fantastical" because "only then do they become credible and arouse indignation," the "convincing framework" which Simonini will choose is completely fictional, namely "the Masonic gathering on Thunder Mountain, [...] Joseph Balsamo's plan and the Jesuits' night in the Prague cemetery" (2540-2545). Eco's character is very aware that conspiracy is primarily a combination of truth and fantasy and knows perfectly well how important the setting of it is: he chooses the cemetery as the background where the Jewish rabbis meet because it instills fear. Unlike in Pynchon's and DeLillo's novels where, as Adrian S. Wisnicki observes, what generates the paranoia associated with the conspiracy are not the machinations of a genuine one, but rather the fear of the protagonists that a conspiracy of huge proportions could be possible, in Eco's novel the mechanisms generating the fear are totally exposed, deciphered, and thus almost made friendly. The forged document must sound familiar-namely containing elements of the popular rhetoric of hatred towards the foreignerand innovative at the same time. Simonini's choices are Dumas, Sue, Joly, and Toussenel. Later on he will add Goedsche's novel Biarritz to complete the list of the main sources of his document (and, of course, of the real Protocols, as 
well). Centered on the well-known fear of the "Jewish plan for the conquest of the world" (Eco 2010, 2545), the text addresses all parts of the society: monarchies, government, clergy, socialists, anarchists, and revolutionaries alike, and it "had to appear in the form of an oral testimony by a witness to that terrible night [of the meeting] — a witness forced on pain of death to remain anonymous" (2560). After this point of the novel Simonini's fictional dimension does not matter anymorethe forgery exists and it will claim its place among the "thoughts" that shaped the world throughout the twentieth century. What is even more extraordinary is the fact that he begins to believe in it himself, just because it was his own creation. He paradoxically becomes a historic villain and a victim of history.

The novel makes the reader aware that "the people who become our enemies often are not those who directly threaten us [...], but those whom someone has an interest in portraying as a true threat when they aren't" (Eco 2012, 110). Later in history the Nazi propaganda used the Protocols and anti-Semitism as a narrative model that explained real events. Hitler denounced the Jews as a foreign element responsible for all the German problems; then he and his leading propagandists "brought [the Protocols] up to date and fleshed it out with the names and faces of recognizable prominent figures" (Herf 2006, 173). Eco's novel warns its reader about the human temptation to believe in fabricated stories and about the use of language as a vehicle of deception, especially when it describes what is familiar. It manages to deconstruct the two great antagonists in the writing of historyfiction and reality - but its purifying operation, as stripped of any ornament as it is in the end, is not meant to return to an originating point, a vanished origin as Badiou called it, but rather to explain an outcome.

And even more-The Prague Cemetery is not just a canonical metatextual novel in which literature returns to itself and investigates its own resources. It goes beyond that-it represents the proof that fiction and reality can function together and that any fiction, once recorded, is able to create its own reality. Its plot seems to be meant to place literature at the confluence of anthropology, iconography, history, and philosophy, all of which are spiced with humor and irony. Its function transgresses the regular use of literature which, as Gabriele Schwab once described it, "unsettles the status quo of habitual cultural codes" and "generates emergent forms of subjectivity, culture and life in processes of dialogical exchange with its readers" (226), but actually explores reality as if it were fictional and conveys the real with a place in fiction. It places itself beyond any type of judgment (and in this aspect those who accused Umberto Eco of antiSemitism cannot be further from reality) illustrating how the history of humanity can be explored taking a journey back, from the "form of thoughts" that shape it towards reality and not the other way around. 


\section{Works cited}

Badiou, Alain. 2012. The Century. Malden: Polity Press.

Eco, Umberto. 2008. Turning Back the Clock. Hot Wars and Media Populism. Orlando: Harcourt Inc.

-. 2012. Inventing the Enemy. (Kindle edition.) Boston, New York: Houghton Mifflin Harcourt.

—. 2010. The Prague Cemetery. (Kindle edition.) Boston, New York: Houghton Mifflin Harcourt.

Girard, René. 1986. The Scapegoat. (Kindle edition.) Baltimore: The Johns Hopkins University Press.

Herf, Jeffrey. 2006. The Jewish Enemy. Nazi Propaganda during World War II and the Holocaust. (Kindle edition.) Cambridge: Harvard University Press.

Schwab, Gabriele. (year not mentioned). Imaginary Ethnographies. Literature, Culture, and Subjectivity. (Kindle edition.) New York: Columbia University Press.

Wisnicki, Adrian S. 2008. Conspiracy, Revolution, and Terrorism from Victorian Fiction to the Modern Novel. (Kindle edition.) New York and London: Routledge. 